\title{
Prevalence of Mycoplasma gallisepticum and Mycoplasma synovae in Poultry- India Perspective
}

\author{
A. Prajapati ${ }^{1 *}$, N. Subhashree ${ }^{1}$, J. Siju Susan ${ }^{2}$, Manjunath G.B. Reddy ${ }^{2}$, \\ R. Yogisharadhya ${ }^{2}$ and S.S. Patil ${ }^{2}$
}

${ }^{1}$ Division of Bacteriology and Mycology, ICAR-Indian Veterinary Research Institute, Izatnagar, Bareilly 243122, India

${ }^{2}$ ICAR-National Institute of Veterinary Epidemiology and Disease Informatics, Bengaluru- 64, India

*Corresponding author

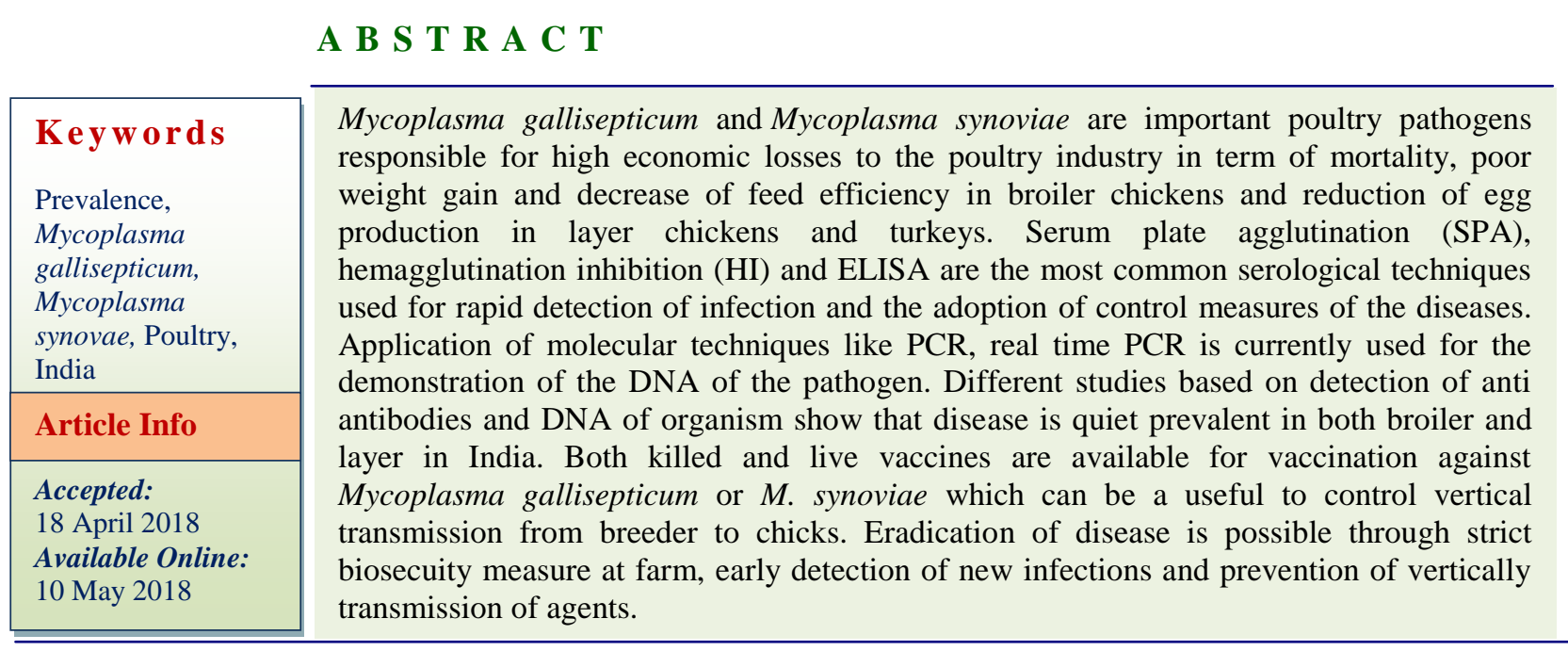

\section{Introduction}

Poultry mycoplasmosis is an important a respiratory diseases of chickens and turkey. Disease is of worldwide distributions and affects both the broiler grower and the layer birds. Poultry industry are facing significant economic losses occurring due to drop in egg production, decrease in egg quality, high embryonic mortality, poor hatchability, high morbidity, poor weight gain and medication costs occur in treatment (Peebles and Branton, 2012).

\section{Etiology}

Avian mycoplasmosis is mainly caused by Mycoplasma gallisepticum and Mycoplasma synoviae species of mycoplasma (OIE, 2008) and less commonly by Mycoplasma meleagridis and Mycoplasma iowae. Organism classified into the class Mollicutes 
Order Mycoplasmatales and Family Mycoplasmataceae. Mycoplasmas are the smallest free living eubacteria but differ from other bacteria not having cell wall. The complete genome sequence of Mycoplasma gallisepticum strain reveal the presence of 996,422 bp with an overall G+C content of 31 mol\% (Papazisi et al., 2003).

\section{Species affected}

Presently mycoplasmosis is one of the most important economic diseases of poultry and particularly affect intensive production systems in most of countries. Of different pathogenic mycoplasma species $M$. gallisepticum is most economically significant and affects mainly gallinaceous avian species. It causes chronic respiratory disease (CRD) in chickens and infectious sinusitis in turkeys. $M$. synoviae is also pathogenic for both chickens and turkeys. All the age groups of turkeys and chickens are susceptible but disease is more common in upto 32 weeks old commercial layer chicken (Udhayavel et al., 2016; Singh et al., 2016). Mycoplasma meleagridis and Mycoplasma iowae is pathogenic primarily for turkeys only.

\section{Transmission}

Poultry mycoplasmas are transmitted through both direct and indirect contact with infected birds and fomites (Kleven, 2008). Horizontal bird-to-bird transmission occurs within flocks through close contact. Infectious aerosols generated after coughing and sneezing of infected birds carry the organism and transmitted it other birds through direct inhalation or contact with infected bird or infected fomites (NneomaOkwara, 2016).

Contaminate feed and water can also transmit the disease. Infected breeders can also transmit the mycoplasma vertically to chicks through in ovo resulting hatched chickens carry the mycoplasma infection (Peebles and Branton, 2012).

\section{Risk factors}

Immune status of birds, litter conditions, stocking density, climate, type of drinker and feeder affects the rate of spread within the flock. Infected fomites and personal carry the organism play important role in between flock transmission (Nneoma Okwara, 2016). Coinfection of $M$. gallisepticum and low pathogenic avian influenza virus (H3N8) in chickens has been reported (Stipkovits et al., 2012) which suggested that LPAI may predispose the birds to $M$. gallisepticum infection and vice versa (Sid et al., 2016). Presence of concurrent infection with ranikhet disease virus, infectious bronchitis virus, colibacillosis or other pathogens make disease more severe (Matilda et al., 2018; Nneoma Okwara, 2016).

\section{Indian scenario}

Recent reports by various workers showed that M. gallisepticum and $M$. synoviae is quite prevalent in different states and geographical location of India and its prevalence varies from $10 \%$ to $55 \%$ and $2 \%$ to $52 \%$ respectively (Table 1 and 2). Seasonal wise study showed that incidence of CRD was observed highest during summer followed by winter and rainy season (Rajkumar et al., 2017).

\section{Prevalence in different countries}

Systematic review of some recent publication showed that $M$. gallisepticum in poultry is highly prevalent in developing countries i.e. $43.50 \%$ layers and $63.5 \%$ broiler in Malaysia (Ching et al., 2016), 45.1\% in Bangladesh (Hossain et al., 2010), 0.9\% Layers and 2.7\% broilers in Belgium (Michiels et al., 2016), $53.40 \%$ in Pakistan (Hussain et al., 2018) and $29.5 \%$ in Accra, Ghana (Matilda et al., 2018). 
Table.1 Prevalence of M. gallisepticum in poultry in India

\begin{tabular}{|c|c|c|c|c|}
\hline State & Samples Size & Test & $\begin{array}{l}\text { Prevalence/Inc } \\
\text { idence }\end{array}$ & References \\
\hline $\begin{array}{l}\text { Some Districts of } \\
\text { Tamil Nadu }\end{array}$ & $\begin{array}{l}1350 \\
\text { Sera sample }\end{array}$ & $\begin{array}{l}\text { ELISA and } \\
\text { SPA }\end{array}$ & $\begin{array}{l}55.5 \% \text { in SPA } \\
\text { and } 42.1 \% \text { in } \\
\text { ELISA }\end{array}$ & $\begin{array}{l}\text { Vadivalagan } \\
\text { et al., } 2018\end{array}$ \\
\hline $\begin{array}{l}\text { Namakkal region of } \\
\text { Tamil Nadu }\end{array}$ & $\begin{array}{l}103 \text { layer sera } \\
\text { samples }\end{array}$ & $\begin{array}{l}\text { Indirect } \\
\text { ELISA }\end{array}$ & $53.40 \%$ & $\begin{array}{l}\text { Udhayavel et } \\
\text { al., } 2016\end{array}$ \\
\hline $\begin{array}{l}\text { Different geographical } \\
\text { regions in the country }\end{array}$ & $\begin{array}{l}1827 \text { serum } \\
\text { samples }\end{array}$ & ELISA & $43.95 \%$ & Reddy, 2014 \\
\hline $\begin{array}{l}\text { Different geographical } \\
\text { regions in the country }\end{array}$ & $\begin{array}{l}1715 \text { Choanal } \\
\text { cleft swabs } \\
\text { samples }\end{array}$ & $\begin{array}{l}\text { Isolation and } \\
\text { PCR }\end{array}$ & $10.38 \%$ & Reddy, 2014 \\
\hline $\begin{array}{l}7 \text { States (Telangana, } \\
\text { Karnataka, } \\
\text { Tamilnadu, Gujarat, } \\
\text { Himachal Pradesh, } \\
\text { West Bengal and } \\
\text { Odisha) }\end{array}$ & $\begin{array}{l}309 \text { Choanal } \\
\text { swabs }\end{array}$ & PCR & $11.65 \%$ & $\begin{array}{l}\text { Rajkumar } e t \\
\text { al., } 2018\end{array}$ \\
\hline $\begin{array}{l}5 \text { States (Telangana, } \\
\text { Karnataka, Gujarat, } \\
\text { Himachal Pradesh, } \\
\text { West Bengal) }\end{array}$ & $\begin{array}{l}635 \text { serum } \\
\text { samples }\end{array}$ & ELISA & $32.6 \%$ & $\begin{array}{l}\text { Rajkumar et } \\
\text { al., } 2018\end{array}$ \\
\hline $\begin{array}{l}\text { Different States }(n=7) \\
\text { of India }\end{array}$ & $\begin{array}{l}1,285 \text { sera } \\
\text { samples }\end{array}$ & ELISA & $32.06 \%$ & $\begin{array}{l}\text { Baksi et al., } \\
2016\end{array}$ \\
\hline Haryana & $\begin{array}{l}92 \text { tissue } \\
\text { samples }\end{array}$ & PCR & $27 \%$ & $\begin{array}{l}\text { Tomar et al., } \\
2017\end{array}$ \\
\hline Haryana & $\begin{array}{l}98 \text { serum } \\
\text { samples }\end{array}$ & RPA & $22.44 \%$ & $\begin{array}{l}\text { Tomar et al., } \\
2017\end{array}$ \\
\hline $\begin{array}{l}\text { Haryana (18 different } \\
\text { hatcheries) }\end{array}$ & $\begin{array}{l}284 \text { serum } \\
\text { samples from }\end{array}$ & RPA & $28.87 \%$ & $\begin{array}{l}\text { Tomar et al., } \\
2017\end{array}$ \\
\hline $\begin{array}{l}\text { Hyderabad } \\
\text { (Organized poultry } \\
\text { farm) }\end{array}$ & $\begin{array}{l}\text { 13,394 dead } \\
\text { birds }\end{array}$ & $\begin{array}{l}\text { Post mortem } \\
\text { examination }\end{array}$ & $11.50 \% \mathrm{CRD}$ & $\begin{array}{l}\text { Rajkumar et } \\
\text { al., } 2017\end{array}$ \\
\hline $\begin{array}{l}\text { Rewa (Madhya } \\
\text { Pradesh) }\end{array}$ & $\begin{array}{l}98 \text { serum } \\
\text { sample }\end{array}$ & ELISA & $21.40 \%$ & $\begin{array}{l}\text { Singh et al., } \\
2016\end{array}$ \\
\hline
\end{tabular}


Table.2 Prevalence of M. synovae in poultry in India

\begin{tabular}{|l|l|l|l|l|}
\hline State & Samples Size & Test & $\begin{array}{l}\text { Prevalence/In } \\
\text { cidence }\end{array}$ & References \\
\hline $\begin{array}{l}\text { 7 States (Telangana, } \\
\text { Karnataka, Tamilnadu, } \\
\text { Gujarat, Himachal } \\
\text { Pradesh, West Bengal } \\
\text { and Odisha) }\end{array}$ & $\begin{array}{l}309 \text { Choanal } \\
\text { swabs }\end{array}$ & PCR & $33.0 \%$ & $\begin{array}{l}\text { Rajkumar } \text { et } \\
\text { al., } 2018\end{array}$ \\
\hline $\begin{array}{l}\text { 5 States (Telangana, } \\
\text { Karnataka, } \\
\text { Gujrat, Himachal } \\
\text { Pradesh, West Bengal) }\end{array}$ & $\begin{array}{l}635 \text { serum } \\
\text { samples }\end{array}$ & ELISA & $52.1 \%$ & $\begin{array}{l}\text { Rajkumar } \text { et } \\
\text { al., 2018 }\end{array}$ \\
\hline $\begin{array}{l}\text { Different states (n=7) of } \\
\text { India }\end{array}$ & 1354 & ELISA & $41.1 \%$ & $\begin{array}{l}\text { Baksi } \text { et al., } \\
2016\end{array}$ \\
\hline $\begin{array}{l}\text { Haryana } \\
\text { Haryana }\end{array}$ & $\begin{array}{l}92 \text { tissue } \\
\text { samples }\end{array}$ & PCR & $2.1 \%$ & $\begin{array}{l}\text { Tomar } \text { et al., } \\
2017\end{array}$ \\
\hline $\begin{array}{l}98 \text { serum } \\
\text { samples }\end{array}$ & RPA & $18.36 \%$ & $\begin{array}{l}\text { Tomar } \text { et al., } \\
2017\end{array}$ \\
\hline $\begin{array}{l}\text { Haryana } \\
\text { (18 different hatcheries) }\end{array}$ & $\begin{array}{l}284 \text { serum } \\
\text { samples }\end{array}$ & RPA & $10.56 \%$ & $\begin{array}{l}\text { Tomar } \text { et al., } \\
\text { 2017 }\end{array}$ \\
\hline Tamilnadu & 116 samples & PCR & $36.2 \%$ & $\begin{array}{l}\text { Senthilnathan } \\
\text { et al., 2015 }\end{array}$ \\
\hline
\end{tabular}

\section{Clinical signs}

\section{M. gallisepticum infection}

M. gallisepticum infection is characterized by respiratory manifestation. The incubation period of chronic respiratory disease varies ranging between 6-21 days. Infected chickens show sign of coughing, sneezing, rales, ocular and nasal discharges. There is decrease in feed consumption, decrease in egg production, increased mortality and poor hatchability. In broilers most outbreaks occur between 3rd and 6th weeks of age that lead to poor feed conversion, sharp decline in weight gain and low carcass quality. In turkeys infection is characterised by swelling of the infra orbital sinus, conjunctivitis and frothy exudates (Peebles and Branton, 2012).

\section{M. synoviae infection}

M. synoviae infection are mostly subclinical in nature and is characterised by milder respiratory distress, lameness, pale comb, swollen hock and foot pad. Infections mainly involve synovial membranes of joints and tendon sheaths resulting exudative synovitis, tendovaginitis, or bursitis (Ferguson and Noormohammadi, 2013). In some cases associated with egg shell apex abnormalities, shell thinning with cracks and breaks (Feberwee et al., 2009).

\section{Diagnosis}

\section{Isolation and Identification of Mycoplasma spp}

M. gallisepticum and $M$. synoviae are relatively fastidious micro-organisms that require special nutritional requirement (Kleven, 2008). Frey medium (Frey et al., 1968), SP-4 medium (Bradbury, 1998), PPLO medium (Kleven, 2008) are some of the commercial available liquid and agar media used for M. gallisepticum / M. synoviae 
isolation. M. synoviae requires extra addition of Nicotinamide adenine dinucleotide (NAD) in the media (Kleven, 2008). Due to lack of cell wall organism is not susceptible to antibiotic acting through cell wall inhibitions. Penicillin $(2,000 \mathrm{IU} / \mathrm{ml})$ and thallium acetate (up to 1:2.000) are added to the growth medium to control other bacterial and fungal contamination. Optimal growth is usually seen at $37^{\circ} \mathrm{C}$ with $5 \% \mathrm{CO} 2$. Colonies are usually seen after 3-5 days post incubation and in solid media organism produce characteristic nipple shaped or fried egg appears colony. Both $M$. gallisepticum and $M$. synoviae ferment glucose and form acid which can be detected by the phenol red indicator (OIE, 2008).

\section{Serological tests}

Serological test like serum plate agglutination (SPA), hemagglutination inhibition

(HI) and enzyme-linked immunosorbent assays (ELISA) are the mostly used for the diagnosis and to study the sero epidemiology of disease (OIE, 2008).

\section{Hemagglutination inhibition}

Test is based on inhibition of haemagglutinating capability of $M$. gallisepticum and $M$. synoviae to avian red blood cells by specific antibodies in sera. HI has high specificity but the disadvantages are low sensitivity (Kleven, 2008).

\section{Serum plate agglutination test}

It is a simple, quick, and inexpensive test for the screening of $M$. gallisepticum and $M$. synoviae antibodies in serum. Positive sample agglutinate the coloured antigen after mixing equal amounts of tested serum sample and stained $M$. gallisepticum or $M$. synoviae antigen. The test has efficient sensitivity but of low specificity (Vadivalagan et al., 2016).

\section{ELISA}

Enzyme-linked immunosorbent assays (ELISA) is sensitive and specific test for the detection of specific antibodies in serum (Ewing et al., 1996). Many commercial ELISA kits are available for the detection of M. gallisepticum and M. synoviae.

\section{Molecular techniques}

Accuracy, time saving, and cost effectively of molecular techniques made them to complementary or even alternative for conventional diagnostic methods. PCR assays proved to be sensitive and specific for $M$. gallisepticum detection. Various PCR assay are described by different worker and used for diagnosis and screening of samples (Rajkumar et al., 2018; Reddy, 2014).

Several PCR primers targeting different genes of $M$. gallisepticum were described previously (Collett et al., 2005). Besides selection of the mgc2 gene sequence has been used successfully for the differentiation of $M$. gallisepticum strains, including field and vaccine strains (Ferguson et al., 2005). Real time PCR is also found a rapid and sensitive test to identify M. gallisepticum-infected flocks (Carli and Eyigor, 2003).

\section{Prevention and control}

\section{Vaccines}

Vaccination is an effective mean for controlling $M$. gallisepticum or M. synoviae in breeder and layer farm and it add to biosecurity measures of farm by enhancing the immunity of birds. Both killed and live vaccines are currently in commercial use. The commercial M. gallisepticum vaccine is used mainly in breeding flocks but also increasingly in laying flocks. 


\section{Killed vaccines}

M. gallisepticum killed vaccines (bacterins) protect young birds from infection with virulent $M$. gallisepticum and commercial egg layers from $M$. gallisepticum-induced drops in egg production (Jacob, et al., 2014). Vaccines have been shown to reduce but not eliminate colonization by $M$. gallisepticum following infection (OIE, 2008).

\section{Live vaccines}

Three types of live vaccine stain ( $\mathrm{F}$ strain vaccine, 6/85 strain vaccine, and ts-11 vaccine) are available for commercial use in poultry for vaccination (Nicholas et al., 2009). Both 6/85 and ts-11vaccines have greater safety and low potential for transmission to unvaccinated flocks in comparison to F strain (Abd-El-Motelib, and Kleven, 1993).

Even though these vaccines are generally safe, F strain may have the potential for infecting unvaccinated flocks transmissible and pathogenic to turkey (Evans, et al., 2005).

\section{Vaccination against $M$. synoviae}

In comparison to $M$. gallisepticum vaccination live vaccination against $M$. synoviae is not frequent in practice and the only $M$. snyoviae $-\mathrm{H}$ vaccine is commercially available vaccine (Nicholas et al., 2009).

\section{Approved vaccine for poultry by Central Drugs Standard Control Organization, India}

M. synoviae Vaccine, Live (strain MS-H)

$M$. gallisepticum Bacterin Vaccine, Inactivated, Oil Emulsion

M. gallisepticum Vaccine, Live

M. gallisepticum Vaccine, Live (strain ts-11).

\section{Biosecurity}

Biosecurity is important mean to prevent the entry and spread of disease in flock. It includes the acquisition of birds free from $M$. gallisepticum and $M$. synoviae antibodies and constant monitoring of breeder flocks. Proper hygiene in farm also play important role in control of avian mycoplasmosis (Racicot et al., 2011). M. gallisepticum infection mainly is transmitted vertically through ovaries hence the preferred method for control is to maintain disease free flocks.

\section{Use of antimicrobials in breeders and eggs}

Mycoplasma is susceptible to antibiotics such as macrolides and lincosamides (tylosin), tiamulin, and fluoroquinolones. Use of antibiotics like tylosin and tiamulin in dipping solution of hatcheries egg have effective role in prevention of vertical transmission of mycoplasma.

\section{References}

Abd-El-Motelib, T.Y. and Kleven, S.H. 1993. A comparative study of Mycoplasma gallisepticum vaccines in young chickens. Avian Dis. 37:981-987.

Baksi, S., Bhumika, F.S., Rao, N., Dave, H. and Malsariya, P. 2016. Sero-prevalence and Risk Factors of Mycoplasma synoviae in broiler breeders in different states of India. J. Immunol. Immunopathol., 18:127-130.

Bradbury, J.M. 1998. Recovery of mycoplasmas from Birds. Methods Mol. Biol., 104: 45-51.

Carli, K.T. and Eyigor, A. 2003. Real-time polymerase chain reaction for Mycoplasma gallisepticum in chicken trachea. Avian Dis. 47(3):712-7.

Ching, G.T., Mahadevan, J., Aini, I., Sheikh, O., Abdul, R., Abdul, R.M. and Nadzri S. 2016. Prevalence of Mycoplasma gallisepticum in commercial chickens and free flying birds. J. Agri.Vet.Sci., 9: 89-95.

Collett, S.R., Thomson A.D.D.K., York, A.D.B. and Bisschop, S.P.R. 2005. Floor pen study 
to evaluate the serological response of broiler breeders after vaccination with TS11 strain Mycoplasma gallisepticum vaccine. Avian Dis. 49:133-137.

Evans, J.D., Leigh, S.A., Branton, S.L., Collier, S.D., Pharr, G.T. and Bearson, S.M.D. 2005. Mycoplasma gallisepticum: Current and developing means to control the avian pathogen. J. Appl. Poult. Res. 14:757-763.

Ewing, M. L., Kleven, S. H. and Brown, M.B. 1996. Comparison of enzyme-linked immunosorbent assay and hemagglutination-inhibition for detection of antibody to Mycoplasma gallisepticum in commercial broiler, fair, and exhibition, and experimentally infected birds. Avian Dis. 40:13-22.

Feberwee, A., de Wit, J.J., Landman, W.J., 2009. Induction of eggshell apex abnormalities by Mycoplasma synoviae: field and experimental studies. Avian Pathol., 38, 7785.

Ferguson, N.M., Hepp, D., Sun, S., Ikuta, N.S.H. and Garcia, M. 2005. The use of molecular diversity of Mycoplasma gallisepticum by gene-targeted sequencing (GTS) and random amplified polymorphic DNA (RAPD) analysis for epidemiological studies. Microbiol., 151:1883-1893.

Ferguson, N.N. and Noormohammadi, H.A. 2013. Mycoplasma synoviae infection. In: Diseases of Poultry, 13th Ed., Swayne DE. editor. Wiley-Blackwell, Ames, Iowa, pp 900-906.

Frey, M.L., Hanson, R.P. and Andrson, D.P. 1968. A medium for the isolation of avian mycoplasmas. Am. J. Vet. Res., 29, 21632171.

Hossain, K.M.M., Hossain, M.T. and Yamato, I. 2010. Seroprevalence of Salmonella and Mycoplasma gallisepticum infection in chickens in Rajshahi and surrounding districts of Bangladesh. Int. J. Biol., 2: 7480.

Hussain, A., Adnan, Y., Mushtaq, A. and Rais, M.N. 2018. Prevalence of Mycoplasma gallisepticum in ross-308 broiler breeder through the contrast of serological assessments in Pakistan. J. Dairy Vet. Anim. Res. 7(1): 00185.
Jacob, R., Branton, S.L., Evans, J.D., Leigh, S.A. and Peebles, E.D. 2014. Effects of live and killed vaccines against Mycoplasma gallisepticum on the performance characteristics of commercial layer chickens. Poult. Sci., 93:1403-1409.

Kleven, S.H. 2008. Control of avian mycoplasma infections in commercial poultry Avian Diseases., 52:367-374.

Matilda, A.A., Kwasi, O.D., Toah-Akonor, P. and Sellers, H.S. 2018. Widespread exposure to infectious bronchitis virus and Mycoplasma gallisepticum in chickens in the Ga-East district of Accra, Ghana. Cogent food agric., 4: 1439260.

Michiels, T., Sarah, W., Mia, V., Christian, Q., Lieze, R., Luc, L., Martelc, A. and Butayea P. 2016. Prevalence of Mycoplasma gallisepticum and Mycoplasma synoviae in commercial poultry, racing pigeons and wild birds in Belgium. Avian Pathol., 45: 244-252.

Nicholas, R.A.J., Ayling, R.D. and McAuliffe, L. 2009 Vaccines for mycoplasma diseases in animals and man. J. Comp. Path., 140: 8596.

NneomaOkwara. 2016. Avian Mycoplasmosis: A Review. J. Agricult. Vet. Sci., 9: 06-10.

OIE. 2008. Manual of Diagnostic tests and Vaccines for Terrestrial Animals. Chapter 2.3.5: Avian mycoplasmosis (Mycoplasma gallisepticum, M. synoviae), pp. 482-496.

Papazisi, L., Gorton, T.S, Kutish, G., Markham, P.F., Browning, G.F., Nguyen, D.K., Swartzell, S., Madan, A., Mahairas, G. and Geary, S.J. 2003. The complete genome sequence of the avian pathogen Mycoplasma gallisepticum strain $\mathrm{R}(\mathrm{low})$. Microbiol. 149: 2307-16.

Peebles, E.D. and Branton, S.L. 2012. Mycoplasma gallisepticum in the commercial egg-laying hen: A historical perspective considering the effects of pathogen strain, age of the bird at inoculation, and diet on performance and physiology. J. App. Poult. Res., 21: 897914.

Racicot, M., Venne, D., Durivage, A. and Vaillancourt, J.P. 2011. Description of 44 biosecurity errors while entering and exiting poultry barns based on video surveillance in 
Quebec, Canada. Prevent. Vet. Med., 100: 193-199.

Rajkumar, S., Reddy, M.R. and Somvanshi, R. 2018. Molecular prevalence and seroprevalence of Mycoplasma gallisepticum and $M$. synoviae in Indian Poultry Flocks. J. Anim. Res., 8: 15-19.

Rajkumar, S.R., Reddy, M.R. and Somvanshi, R. 2017. Incidence and risk factors of chronic respiratory disease in Indian poultry flocks. Int. J. Sci. Env. Tech., 6: $662-668$.

Reddy, M.R. 2014. Prevalence of Mycoplasma gallisepticum infection in Indian poultry farms. International Conference on Animal and Dairy Sciences, September, $15-17^{\text {th }}$, 2014 HICC, Hyderabad, India.

Senthilnathan, G., Shenbagam, S., Suryanarayana, T. and Thiyageeswaran. M. 2015. Isolation and molecular confirmation of Mycoplasma synoviae infection from broiler breeder farms in Tamilnadu. Indian J. Anim. Res., 49: 91-94.

Sid, H., Hartmann. S., Petersen, H., Ryll, M. and Rautenschlein, S. 2016. Mycoplasma gallisepticum modifies the pathogenesis of influenza A virus in the avian tracheal epithelium. Int. J. Med. Microbiol., 306(3):174-86.

Singh, N., Shukla, S. and Sharma, V. 2016. Detection of Anti Mycoplasma gallisepticum Antibodies in Different Age Group of Chicken by Enzyme Linked Immunosorbant Assay. J. Anim. Res., 6: 1, 2249-5290.
Stipkovits, L., Egyed, L., Palfi, V., Beres, A., Pitlik, E., Somogyi, M., Szathmary, S. and Denes, B. 2012. Effect of low-pathogenicity influenza virus $\mathrm{H} 3 \mathrm{~N} 8$ infection on Mycoplasma gallisepticum infection of chickens. Avian Pathol., 41(1):51-7.

Tomar, P., Singh, Y., Kundu, P., Narang, G. and Neelam, R. 2017. Seroprevalence of Mycoplasma gallisepticum and Mycoplasma synoviae antibodies by rapid plate agglutination test in broiler chicken flocks of Haryana. Int. J. Adv. Biological Res., 7 (4): 757-760.

Tomar, P., Singh, Y., Mahajan, N.K., Jindal, N. and Singh, M. 2017. Molecular Detection of Avian Mycoplasmas in Poultry Affected with Respiratory Infections in Haryana (India). Int. J. Curr. Microbiol. App. Sci., 6(6): 2155-2162.

Udhayavel, S., Murthy, T.R.G.K., Gowthaman, V., Senthilvel, K. and Sureshkumar, G. 2016. Detection of sub clinical infection of Mycoplasma gallisepticum in commercial chicken by indirect ELISA. Adv. Anim. Vet. Sci. 4(8): 438-440.

Vadivalagan, K., Sukumar, K., Sudha, R.V., Sivachandran, M., Logesh, P. and Dorairajan, R. 2016. Seroprevalence and comparative study of serological tests for detection of Mycoplasma gallisepticum infection in commercial layer farms. Indian J. Animal Res., DOI: 10.18805/ijar.8593.

\section{How to cite this article:}

Prajapati, A., N. Subhashree, J. Siju Susan, Manjunath G.B. Reddy, R. Yogisharadhya and Patil S.S. 2018. Prevalence of Mycoplasma gallisepticum and Mycoplasma synovae in Poultry- India Perspective. Int.J.Curr.Microbiol.App.Sci. 7(05): 2213-2220.

doi: https://doi.org/10.20546/ijcmas.2018.705.258 